\title{
ASPECTOS GEOECONÔMICOS DA CADEIA PRODUTIVA DA SOJA NO ESTADO DE SANTA CATARINA: PRODUÇÃO E CIRCULAÇÃO GEOECONOMIC ASPECTS OF THE SOYBEAN PRODUCTION CHAIN IN THE STATE OF SANTA CATARINA: PRODUCTION AND CIRCULATION
}

\author{
Roberto César Costa Cunha ${ }^{1}$, Wander Luís de Melo Cruz ${ }^{1}$ \\ ${ }^{1}$ Universidade Federal de Santa Catarina (UFSC), Florianópolis, SC, Brasil
}

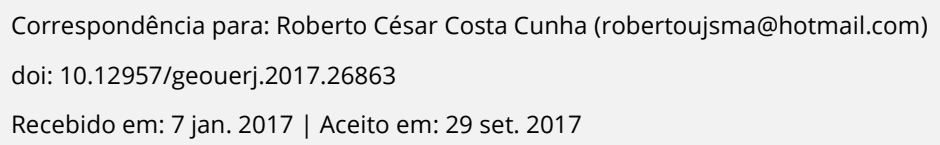

\section{RESUMO}

Este artigo tem por objetivo demonstrar algumas das recentes transformações que ocorreram desde a década de 1990 na cadeia produtiva da soja, tendo como recorte espacial o estado de Santa Catarina. Nele abordamos alguns dos principais elementos que justificam o dinamismo e à expansão da cultura da soja no território catarinense, assim como analisamos às rotas e o quadro de transportes e logística agroindustrial da soja em Santa Catarina. É interesse analisarmos como o dinamismo do agronegócio brasileiro está associado aos fatores internos "da porteira para dentro", enquanto os principais pontos de estrangulamento estão geralmente associados à fatores externos "da porteira para fora" como a literatura costuma apontar. Nesse trabalho demonstramos de forma concisa à assimetria qualitativa e quantitativa entre agentes e as infraestruturas responsáveis pela produção e circulação da soja em Santa Catarina.

Palavras-chave: Cadeia produtiva da soja; Santa Catarina; Produção; Transportes e logística.

\begin{abstract}
This article aims to demonstrate some of the recent changes that have occurred since the 1990s in the soybean production chain, with the spatial area the state of Santa Catarina. We covered some of the key elements that justify the dynamism and expansion of the soybean crop in the state of Santa Catarina, as well as analyze the routes and the transport frame and agro-logistics soy in Santa Catarina. It is interest we analyze how the dynamism of Brazilian agribusiness is associated with internal factors "of the gate inside," while the main bottlenecks are usually associated with external factors "the gate out" as the literature often point. In this work we demonstrate concisely the qualitative and quantitative asymmetry between agents and infrastructure responsible for the production and soybean movement in Santa Catarina.
\end{abstract}

Keywords: Production chain soy; Santa Catarina; Production; Transport and logistics.

\section{INTRODUÇÃO}

Conforme assinalam Santos; Silveira (2012), a cultura da soja no Brasil, que se estabeleceu primeiramente nos estados do sul do Brasil, já nasceu com altos rendimentos e, desde os anos de 1970 , é responsável por inúmeras metamorfoses e especializações produtivas do espaço agrário brasileiro. Apontam, também, Espíndola; Cunha (2015), que a cadeia produtiva ${ }^{1}$ da soja configura-se como o

\footnotetext{
${ }^{1}$ No presente texto, optou-se pelo conceito de cadeia produtiva. As cadeias produtivas possuem entre os seus componentes ou subsistemas os diversos sistemas produtivos agropecuários e agroflorestais nos quais ocorre a produção agrícola. Segundo 
carro-chefe da agricultura de grande escala no Brasil, chancelando o país como segundo produtor mundial e confirmando-o como o primeiro exportador de soja do mundo.

Em Santa Catarina, a produção de soja equivale a $2 \%$ da produção nacional, sendo a $11^{\text {a }}$ unidade da federação (UF), que mais produz soja no território brasileiro (CONAB, 2016). No ano safra 2014/2015, foram produzidas 1,9 milhão de toneladas de grãos em 600 mil hectares. Cerca de 80\% (1,5 milhão de toneladas), da produção de grãos, em 2015, foi exportada. E o conjunto dos portos de Santa Catarina embarcou 4,8 milhões de toneladas, sendo, que o porto de São Francisco do Sul embarcou 4,6 milhões, auferindo receita de U\$S 1,7 bilhão.

Desse modo, entende-se que o estado de Santa Catarina seja rota de exportação de grãos de soja provenientes de outras unidades federativas, especialmente do Rio Grande do Sul, do Paraná, do Mato Grosso do Sul e do Mato Grosso. Grande parcela do transporte dos grãos é realizado exclusivamente pelo modal rodoviário, isso porque o oeste catarinense não conta com uma infraestrutura ferroviária, terminais de transbordo de grãos alfandegados e nenhuma plataforma logística, contribuindo assim, para aumento dos custos logísticos e a diminuição da competitividade na exportação de grãos.

Esses fatores da produção e circulação da soja em Santa Catarina per se já justificariam esse texto, mas outros elementos ainda fazem-se necessários, entre eles, a bibliografia que inclui: livros; artigos em periódicos indexados; dissertações; teses: e etc. Em parte dessa revisão, objetivou-se identificar quais os elementos responsáveis pelo aumento produção (e também da produtividade) e pelo desenvolvimento das redes técnicas que propiciam à circulação da soja no estado catarinense. Em termos gerais, destacam-se precisamente: Pinheiro \& Fukasaku (2000); Santos \& Silveira (2012); Barat (2007; 2011); Hara (2013); Pinheiro \& Frischtak (2014) e Oliveira (2014) que em seus

Castro (2002, p. 6-7), “o enfoque de cadeia produtiva provou sua utilidade, para organizar a análise e aumentar a compreensão dos complexos macroprocessos de produção e para se examinar o desempenho desses sistemas, determinar gargalos ao desempenho, oportunidades não exploradas, processos produtivos, gerenciais e tecnológicos. Ao incorporar na metodologia alternativas para análise de diferentes dimensões de desempenho das cadeias produtivas ou de seus componentes individualmente, como a eficiência, qualidade, competitividade, sustentabilidade e a equidade, esta tornou-se capaz de abranger campos sociais, econômicos, biológicos, gerenciais, tecnológicos, o que ampliou possíveis aplicações desse enfoque para um grande número profissionais e de instituições. Entre estas aplicações, aquelas relacionadas com a prospecção tecnológica e não tecnológica”. 
estudos diagnosticaram à assimetria entre o desenvolvimento do setor produtivo e dos sistemas de transportes e armazenamento no Brasil; o relatório do Instituto de Planejamento e Economia Agrícola de Santa Catarina (ICEPA), do ano de 2015, que ressalta que o principal indicador para o crescimento do plantio da soja em Santa Catarina é a relação entre preço e custo da soja e a rentabilidade proporcionada por essa cultura.

Esses trabalhos oferecem férteis elementos para à compreensão das múltiplas determinantes da produção e circulação da soja no Brasil e Santa Catarina. Entretanto, em que pese à importância desses, às análises acabam por reforçar a preponderância de alguns fatores sobre o outros, emergindo pontos estrangulados quando analisamos todos os elos que compõe a rede da cadeia produtiva da soja no estado de Santa Catarina. Partindo disso, o objetivo deste artigo é abordar os aspectos gerais relacionados à produção e a circulação da soja no estado de Santa Catarina, apontando seu dinamismo e pontos de estrangulamentos de toda a cadeia produtiva da soja no estado.

Para tanto, utilizar-se-á a categoria formação socioespacial (FSE). Segundo Santos (1977), essa categoria foi inicialmente criada para explicar a evolução de uma sociedade em sua realidade concreta. A mesma não pode ser entendida sem a noção de espaço geográfico (produto e condição de reprodução das relações sociais), passando então a assumir o status de formação histórica e geograficamente localizada. Assim, cada formação sócioespacial é singular, onde os processos gerais interagem com as características particulares, gerando combinações geográficas específicas ${ }^{2}$.

Dessa escolha analítica, a metodologia de pesquisa usada para a elaboração do artigo foi o exploratório-analítico. As pesquisas exploratórias envolvem levantamento bibliográfico, documental, entrevistas, pesquisas de campo e estudos de caso (GIL, 1994). Funcionalmente, o artigo foi

\footnotetext{
${ }^{2}$ As combinações geográficas que são extremamente importantes para se ter uma aproximação fiel da realidade. Conforme Cholley (1964) essas combinações podem se três tipos: (i) aquelas que convergem de fatores físicos (a geomorfologia, a hidrologia etc.); (ii) aquelas de complexidade maior de ordem física e de ordem biológica (o cerrado); e (iii) aquela de ordem tridimensional, mais complicadas e muito mais requintadas de detalhes, de ordens físicas, biológicas e humanas (agricultura, indústria, comércio). Essas combinações geográficas são similares a que Marx (2011) chamou de 'múltiplas determinações', que ampliam as possibilidades das análises, pois a realidade é fruto da relação dialética entre os aspectos naturais e humanos. Essas relações são estabelecidas em múltiplas escalas (mundial, nacional, regional e local), e permitem compreender um determinado objeto de estudo num universo mais amplo.
} 
desenvolvido com base em parâmetros bibliográficos e documentais, fundamentado em fontes primárias, secundárias e pesquisas de campo de modo encadeado. Quanto às fontes primárias, recorreu-se a informações e dados dos relatórios técnicos da Companhia Nacional de Abastecimento (CONAB), ao banco de dados dos censos do Instituto Brasileiro de Geografia e Estatística (IBGE) e aos relatórios técnicos do ICEPA, relatórios técnicos da Agência Nacional de Transportes Aquaviários (ANTAQ), nos relatórios do Ministério da Agricultura, Pecuária e Abastecimento (MAPA), nos relatórios técnicos do Ministério do Desenvolvimento, Indústria e Comércio Exterior (MDIC). Dentre as fontes secundárias, destacam-se artigos em periódicos indexados, teses, dissertações, livros, revistas especializadas, sítios de entidades empresariais e governamentais na internet. As atividades empíricas (visitas técnicas) - trabalho de campo — foram realizadas: (i) região do Planalto Norte Catarinense (Canoinhas, Mafra, Major Vieira) com produtores de soja em outubro de 2016; (ii) nos portos de São Francisco do Sul (SC), Itapoá (SC), Itajaí/Navegantes (SC) e Imbituba (SC), bem como em sua respectiva retroárea, em diversas oportunidades nos anos de 2014, 2015 e 2016.

Ademais, a estrutura do artigo, para alcançar o objetivo central indicado, está repartida em quatro seções, não excetuando esta introdução. A segunda seção apresenta-se as principais características da produção de soja de Santa Catarina. Na terceira analisam-se as principais combinações determinantes da circulação da soja no estado. E, por derradeiro, são apresentadas algumas conclusões acerca do tema em tela.

\section{PRODUÇÃO DE SOJA EM SANTA CATARINA}

A cultura de soja, em 1940, passa a ter importância econômica no Rio Grande do Sul; nas duas décadas posteriores, a soja avança para Santa Catarina e Paraná, em 1969, esses estados são responsáveis por produzir 98\% de toda a produção brasileira (BONATO, 1981). Nessa época, a área plantada era menos de menos de um milhão de hectares e a produção pouco mais de um milhão de toneladas (BONATO, 1981; DALL AGNOL, 2004; CAMPOS, 2010). Como resultado de inúmeras 
combinações $^{3}$, o Brasil na safra de 2014/2015 atingiu uma produção de 96,2 milhões de toneladas de grãos de soja em mais de 32 milhões de hectares (CONAB, 2016). As exportações da cadeia produtiva da soja também deram um salto de volume, tanto em grãos como em receita. Em 2015, as exportações de grãos soja do país bateram mais de 54 milhões de toneladas. Entre 2001 (U\$S 5,2 bilhões) e 2014 (US\$ 31, 4 bilhões), a cadeia da soja obteve um aumento nas receitas de mais de U\$S 26 bilhões (BRASIL 2016). Segundo Cepea (2016), o PIB da cadeia da soja atingiu R $\$ 91,3$ bilhões. Esse desempenho mostra que a cadeia da soja é importante para economia brasileira, pois gera renda e emprego, e contribui para a estabilidade da macroeconômica do país por meio de seu faturamento, ajudando a amenizar o déficit da balança comercial.

Em Santa Catarina (ver figura 01), conforme assinala Bonato; Bonato (1987, p.16), a introdução da soja, foi feita por agricultores oriundos do Rio Grande do Sul, que se fixaram no oeste do estado e no Vale do Rio do Peixe, por volta dos anos de 1930. Em 1944, foi expandida a cultura em Santa Catarina com o intuito de utilizá-la na confecção de cola para a indústria madeireira. No ano safra de 1951/1952, a produção de soja atingiu cerca de 51 toneladas com uma área cultivada de 40 hectares e com produtividade média de $1.275 \mathrm{~kg} / \mathrm{ha}$.

\footnotetext{
${ }^{3}$ No presente texto, optou-se pelo conceito de cadeia produtiva. As cadeias produtivas possuem entre os seus componentes ou subsistemas os diversos sistemas produtivos agropecuários e agroflorestais nos quais ocorre a produção agrícola. Segundo Castro (2002, p. 6-7), "o enfoque de cadeia produtiva provou sua utilidade, para organizar a análise e aumentar a compreensão dos complexos macroprocessos de produção e para se examinar o desempenho desses sistemas, determinar gargalos ao desempenho, oportunidades não exploradas, processos produtivos, gerenciais e tecnológicos. Ao incorporar na metodologia alternativas para análise de diferentes dimensões de desempenho das cadeias produtivas ou de seus componentes individualmente, como a eficiência, qualidade, competitividade, sustentabilidade e a equidade, esta tornou-se capaz de abranger campos sociais, econômicos, biológicos, gerenciais, tecnológicos, o que ampliou possíveis aplicações desse enfoque para um grande número profissionais e de instituições. Entre estas aplicações, aquelas relacionadas com a prospecção tecnológica e não tecnológica”.
} 


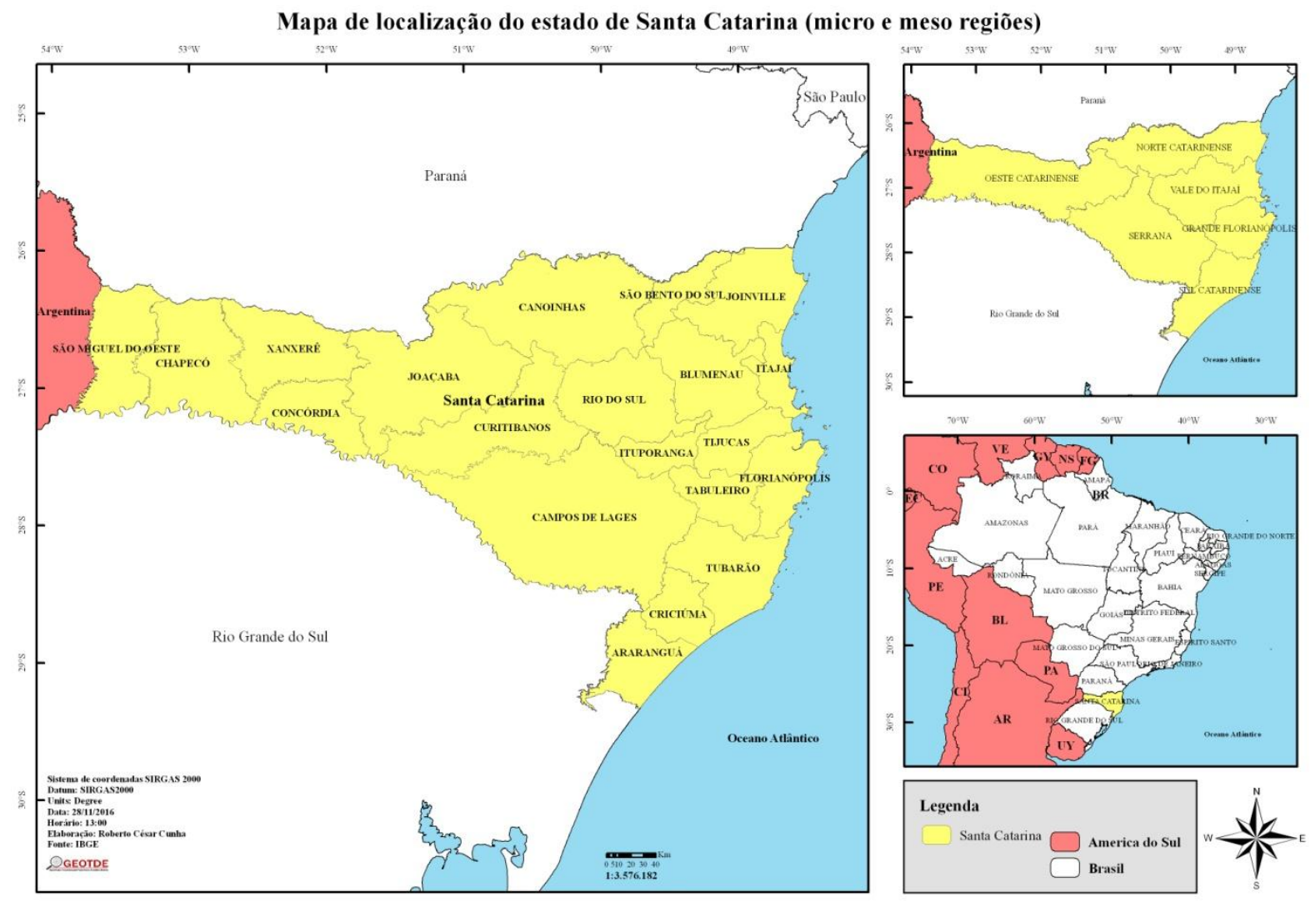

Figura 1 Mapa de localização de Santa Catarina e suas regiões

Fonte: IBGE. Organização: autores

No estado de Santa Catarina a soja permaneceu sem expressão econômica até por volta do final dos anos 1960, em que ocasião ocorreram às primeiras iniciativas para a comercialização. Até aquele momento, a soja era cultivada em pequenas propriedades (HYMOWITZ; VERNETTI; SHANDS, 1968), sendo sua produção empregada como forrageira e para a alimentação de animais (suínos e frangos), ou seja, a soja foi um mero apêndice de outras atividades mais importantes como a suinocultura e o plantio de feijão, milho e trigo (HASSE, 1996). A escolha da cultura da soja foi em consórcio com o milho para a ocupação das terras até então ociosas no período do verão. Os produtores buscavam alternativas de cultivo na entressafra do milho, normalmente produzindo cereais utilizados na alimentação de suínos, até a implementação da soja. Com isso, a cultura de soja aproveitou-se da estrutura agrícola e agrária ${ }^{4}$ do estado catarinense, o que possibilitou sua expansão. No início, em

\footnotetext{
${ }^{4}$ Segundo Mamigonian (1965), a ocupação do território catarinense, a partir do século XVII, por paulistas; século XVIII, por açorianos; e século XIX e XX, por imigrantes alemães, italianos, polacos, entre outros, resultou na constituição de duas grandes estruturas agrárias. Uma caracterizada pela presença de grandes estâncias de gado (Planalto) e, a outra, localizada na fachada atlântica e oeste do estado, assentada no estabelecimento de milhares de pequenos agricultores, artesãos, operários, pequenos comerciantes, que já praticavam uma significativa divisão social do trabalho. Assim, enquanto nas áreas de campo
} 
Santa Catarina, o cultivo da soja, apesar pequeno, manifestou-se mecanizado e moderno desde as primeiras colheitas.

No ano safra de 1964/1965, o estado catarinense participava com cerca de $1 \%$ da produção nacional (BONATO; BONATO, 1987). Em 1985, Santa cataria obteve 3,17\% da produção brasileira, apresentando, em 432 mil hectares de área colhida, uma produção de 578,9 mil toneladas de grãos, com rendimento médio de $1.340 \mathrm{~kg} / \mathrm{ha}$, segundo Conab (2016).

Cabe destacar, como afirma Espíndola (2002), que as inovações, no que tange a política agrícola por parte do governo federal, surgem após o golpe civil militar de 1964, com a criação do Sistema Nacional de Crédito Rural (SNCR), do Plano de Ação Econômica do Governo (PAEG) e do Fundo Geral para a Indústria e Agricultura (FUNAGRI), que reunia o Fundo de Democratização do Capital (FUNDECE), o Fundo de Financiamento à Importação de Bens de Produção (FIBEP) e o Fundo Nacional de Refinanciamento Rural. Em termos de crédito rural do SNCR, destaca-se que, entre 1973-1980, o crédito cresceu 355\% no estado de Santa Catarina, enquanto no Brasil cresceu apenas 16,09\%. Do montante do crédito aplicado, 35\% foram destinados à pecuária (suínos e aves) e o restante para lavouras de soja, milho, fumo, arroz e feijão. Entre 1969-1981, enquanto o valor do crédito de custeio para cultura de arroz subiu 2,9 vezes pulando de 1,6 milhão de cruzeiros para 5,0 milhões de cruzeiros, o crédito para cultura de feijão cresceu 84 vezes (ESPÍNDOLA, 2002). Essas transformações possibilitaram a formação de grandes grupos econômicos no estado de Santa Catarina no setor alimentício, sobretudo, à expansão da soja. A Cereais do Vale Ltda (Ceval), foi montada, em

desenvolveu-se a atividade da pecuária extensiva, nas áreas de mata, assentada em pequenas propriedades, desenvolveu-se uma produção mercantil diversificada de produtos agropecuários. Nas áreas de pequenas propriedades, o desenvolvimento agrário se fez em diferentes estágios. 0 primeiro, por meio do sistema de rotação de terras; o segundo, caracterizado pela utilização do arado, a introdução de novas culturas e a implantação de moinhos; e o terceiro, assentado na rotação de culturas, no uso combinado da lavoura e da pecuária, no beneficiamento de seus produtos e na introdução e comercialização de novas atividades, conforme demonstrou Waibel (1979). Espíndola (2002) assinala que, a partir de 1950, essa estrutura assentada na pequena produção mercantil começa a passar por profundas transformações de ordem técnica e econômica: (1) a extensão rural possibilitou novas técnicas de produção e organização da propriedade, objetivando o aumento da produção e da produtividade; (2) implantação, por parte da empresa Sadia, de um projeto de conquista de pequenos produtores capazes de desenvolver a criação de suínos; (3) introdução da avicultura no oeste de Santa Catarina, por parte do Grupo Sadia; (4) surgimento dos bancos estaduais e regionais de fomento (BDE e o BRDE), bem como pela política tecnológica e creditícia do governo federal; (5) introdução de novas culturas, como por exemplo, a soja e a maçã; (6) a estrutura fundiária se manteve predominante em estabelecimentos concentrados nos estratos de menor tamanho; (7) houve redução do número de proprietários por estabelecimento e aumento do número de arrendatários, parceiros e ocupantes, entre 1960-1980. 
1972 em Gaspar, no vale do rio Itajaí-Açu, com os mesmos incentivos fiscais que tinha direito o grupo Hering (HASSE, 1996) . ${ }^{5}$

Entre a segunda metade dos anos 1980 e o final dos anos 1990 a produção de grãos de soja em Santa Catarina permaneceu estável, na órbita média de 500 mil toneladas ano, com uma redução na área plantada, no mesmo período, de aproximadamente de 45\%, no entanto, produtividade média aumentou mais de 53\% (CONAB, 2016). Esse aumento, sobretudo, na produtividade média da soja, merece destaque a performance da Embrapa que, por intermédio do CNPSo de Londrina, que se empenhou em desenvolver uma tecnologia específica para produção do grão em regiões de latitude inferiores a $15^{\circ} \mathrm{s}$, e para o aumento da produtividade em áreas tradicionais (CAMPOS, 2010). Outras combinações ajudar a explicar o desempenho da produção de soja catarinense, entre 2003-2011 ${ }^{6}$. Dentre elas, podem-se destacar: (i) as crises de aftosa e vaca louca na Europa e nos EUA; (ii) a redução da oferta mundial de carne de frango por parte da China e dos EUA, em razão do crescimento de sua demanda interna (ESPÍNDOLA, 2016); e (iii) a conquista de novos nichos de mercados que ampliaram o market share (NAKAHODO; JANK 2006); e (iv) a grande disponibilidade de terra, água, boas pastagens, condições climáticas e outros fatores naturais que tornam a cadeia produtiva de soja competitivas internacionalmente.

\footnotetext{
${ }^{5}$ Segundo Hasse (1996, p. 54-55), “a arrancada de Ceval coincide com o início da era dos grandes investimentos feitos por grupos privados nacionais e estrangeiros em pontos estratégicos do território nacional, já acompanhando a arrancada dos agricultores sulinos rumo ao centro do Brasil. Na chamada fase moderna da soja, iniciada em 1973, Ponta Grossa firma-se como o maior centro processador de soja do hemisfério sul, graças às unidades industriais montadas na cidade pela Cargill, Sanbra e Irmãos Pereira (hoje Coinbra). Ainda na década de 70, a implantação de novas fábricas ou a conversão para a soja de antigas processadoras de outros óleos vegetais estabeleceram o domínio do mercado para um seleto grupo de multinacionais representado pelo Bunge y Born (Sanbra/Samring), Anderson Clayton e Cargill, seguido pela "chinesa" Olvebra e por diversas cooperativas, que em determinado momento chegaram a ter nas mãos perto de $50 \%$ da força da soja. Se muitos empreendedores montaram indústrias de óleos para aproveitar financiamentos subsidiados e incentivos fiscais à exportação, houve também casos em que a prioridade foi o mercado interno. Os exemplos mais notórios são os da Sadia e Perdigão, que montaram unidades de processamento de soja, em meados da década de 70, para atender às próprias necessidades de ração para suas granjas integradas de frango suíno. Rápido e intenso, esse processo de verticalização fez da Sadia o maior fabricante nacional de rações, seguida pela Ceval, que efetuou a verticalização no sentido contrário - da soja para as carnes". Também afirma Espíndola (2002, p. 129) que a Ceval se mostrou uma empresa agressiva e progressiva em inversões, sobretudo, no setor da soja. Esses investimentos atingiram certa de U\$S 101,6 milhões. No final dos anos 1990, a Ceval foi adquirida pelo grupo Bunge Born, por mais de U\$S 400 milhões com intuito de sanear as finanças da Hering Têxtil. Neste período a Ceval possuía: $25,7 \%$ do martket share nacional de óleo vegetal; $27 \%$ de óleos vegetais refinados; $11,1 \%$ de margarinas; $13,5 \%$ do esmagamento total da soja no Brasil; $14,4 \%$ do mercado de carne.

${ }^{6}$ Ver Espíndola (2016), Bielschowsky (2013) e (BARBOSA, 2013) que apontam que a economia brasileira, entre 2003 e 2011, passou pelo ciclo de expansão do crescimento econômico.
} 
Partindo disso, como se demonstra na tabela 01, a produção de grãos de soja aumentou, no período 2003-2015, mais de 160\%. A área plantada aumentou 135,2\%, no período em tela, e a produtividade avançou 10,8\%. Além das combinações já assinaladas (de conjuntura econômica e estrutura técnica produtiva), um fator que ajuda a elucidar esse crescimento é a relação preço/custo da soja no mercado e a renda possibilitada por essa cultura, que influencia diretamente na escolha entre a soja, e como, por exemplo, o milho. Segundo o Icepa (2015, p. 61), "a relação entre custos de produção e da capacidade de rendimento das culturas, em geral, quando o preço da soja é pelo menos 2,3 vezes o preço do milho, a produção de soja é mais favorável ao produtor, que opta pela oleaginosa ${ }^{7} "$.

\begin{tabular}{l|c|c|c}
\hline & Área plantada (1000 ha) & Produção (1000 ton.) & Produtividade (Kg/ha) \\
\hline $\mathbf{2 0 0 3}$ & 255,8 & 738,5 & 2.887 \\
\hline $\mathbf{2 0 0 4}$ & 307,0 & 656,7 & 2.139 \\
\hline $\mathbf{2 0 0 5}$ & 350,0 & 644,0 & 1.840 \\
\hline $\mathbf{2 0 0 6}$ & 344,8 & 827,5 & 2.400 \\
\hline $\mathbf{2 0 0 7}$ & 376,9 & $1.104,3$ & 2.930 \\
\hline $\mathbf{2 0 0 8}$ & 373,4 & 946,6 & 2.535 \\
\hline $\mathbf{2 0 0 9}$ & 385,3 & 974,8 & 2.530 \\
\hline $\mathbf{2 0 1 0}$ & 439,6 & $1.345,2$ & 3.060 \\
\hline $\mathbf{2 0 1 1}$ & 458,2 & $1.489,2$ & 3.250 \\
\hline $\mathbf{2 0 1 2}$ & 448,3 & $1.084,9$ & 2.420 \\
\hline $\mathbf{2 0 1 3}$ & 512,5 & $1.578,5$ & 3.080 \\
\hline $\mathbf{2 0 1 5}$ & 542,7 & $1.644,4$ & 3.030 \\
\hline
\end{tabular}

Tabela 1 - área plantada, produção e produtividade da soja em Santa Catarina Fonte: Conab (2016)

Portanto, houve a substituição das áreas de milho para a expansão das áreas de soja. Entre 2003 e 2015 houve uma diminuição de pouco mais de 50\% na área plantada de milho, com prejuízo à produção total no estado do cereal ${ }^{8}$.

\footnotetext{
${ }^{7}$ Informação, também confirmada, em entrevista realizada com a família Ruthes, produtora de soja em Major Vieira (SC), em outubro de 2016 em Major vieira (SC).

8 A produção de milho em Santa Catarina, mesmo com mais de 50\% da área plantada reduzida entre 2003 e 2015, sofreu queda relativa. Segundo Conab (2016), em 2003 a produção atingiu cerca de 4,2 milhões de toneladas, com uma produtividade média de 4,9 toneladas por hectare. No entanto, em 2015, a produção de milho no estado alcançou 3,1 milhões de toneladas, que representa uma queda acumulada no período de $26,2 \%$. Porém o rendimento médio, no mesmo espaço de tempo, expandiu-se cerca de 55,3\% e bateu a marcar de 7,75 toneladas por hectares (CONAB, 2016), fazendo Santa Catarina o estado com maior produtividade do Brasil.
} 


\begin{tabular}{|c|c|c|c|c|c|c|c|c|c|c|c|c|}
\hline \multicolumn{13}{|c|}{ Área plantada de soja em Santa Catarina (em hectares) } \\
\hline Microrregião & 2003 & 2004 & 2005 & 2006 & 2007 & 2008 & 2009 & 2010 & 2011 & 2012 & 2013 & 2014 \\
\hline Curitibanos & 37275 & 44878 & 51700 & 45180 & 51740 & 55950 & 56080 & 64930 & 69680 & 71535 & 82300 & 86430 \\
\hline Xanxeré & 80750 & 94109 & 102845 & 96295 & 115925 & 111700 & 111950 & 127480 & 127450 & 121300 & 125200 & 131580 \\
\hline Joaçaba & 10651 & 14954 & 17770 & 17440 & 20045 & 21380 & 22425 & 25180 & 29350 & 31761 & 36263 & 41480 \\
\hline Chapecó & 44425 & 53685 & 59062 & 51815 & 58905 & 57175 & 60122 & 70710 & 76410 & 72020 & 78880 & 83610 \\
\hline São Miguel do Oeste & 12970 & 19548 & 23185 & 20080 & 23940 & 23300 & 24370 & 28820 & 30000 & 30670 & 33840 & 35440 \\
\hline Campos de Lages & 3050 & 4920 & 9770 & 10750 & 11700 & 11900 & 12350 & 15650 & 17070 & 24840 & 37440 & 41450 \\
\hline Canoinhas & 63150 & 76440 & 82310 & 83030 & 96560 & 85390 & 89510 & 97910 & 99100 & 91450 & 110380 & 120000 \\
\hline \multicolumn{13}{|c|}{ Área plantada de milho em Santa Catarina (em hectares) } \\
\hline Curitibanos & 50690 & 47100 & 47750 & 52500 & 42900 & 45080 & 45580 & 40100 & 37500 & 39803 & 34620 & 29420 \\
\hline Xanxeré & 85590 & 81177 & 82530 & 84985 & 63213 & 64213 & 53545 & 39275 & 38375 & 41220 & 40030 & 35230 \\
\hline Joaçaba & 87430 & 89400 & 89400 & 86960 & 83200 & 83050 & 87500 & 86080 & 78450 & 75754 & 70503 & 64373 \\
\hline Chapecó & 201423 & 197690 & 180305 & 165020 & 153153 & 152095 & 129787 & 106695 & 95159 & 77140 & 72180 & 69300 \\
\hline São Miguel do Oeste & 123650 & 107579 & 112953 & 108210 & 90515 & 90275 & 77627 & 71935 & 57910 & 60120 & 59130 & 54640 \\
\hline Campos de Lages & 46960 & 46425 & 47940 & 48649 & 48840 & 52860 & 49170 & 46220 & 45480 & 40965 & 41550 & 37830 \\
\hline Canoinhas & 77200 & 70100 & 71400 & 77100 & 59350 & 77200 & 69900 & 63800 & 66900 & 66200 & 53700 & 46150 \\
\hline \multicolumn{13}{|c|}{ Produção de soja em Santa Catarina (em toneladas) } \\
\hline Curitibanos & 96233 & 65012 & 64434 & 91602 & 146070 & 135160 & 137020 & 198933 & 215974 & 178631 & 221194 & 301922 \\
\hline Xanxerê & 239790 & 201749 & 168436 & 257122 & 343681 & 273096 & 326460 & 418280 & 437795 & 255469 & 410850 & 381688 \\
\hline Joaçaba & 28199 & 26827 & 25472 & 34919 & 49991 & 48637 & 53926 & 75613 & 88826 & 84484 & 103032 & 137257 \\
\hline Chapecó & 111242 & 95628 & 67440 & 125047 & 149506 & 134820 & 140564 & 207758 & 234294 & 126902 & 221641 & 215019 \\
\hline São Miguel do Oeste & 37040 & 36691 & 27599 & 49088 & 63872 & 55653 & 50385 & 84983 & 96543 & 47220 & 90564 & 76946 \\
\hline Campos de Lages & 8168 & 10208 & 20287 & 17583 & 27810 & 30060 & 26290 & 38220 & 49077 & 67257 & 101370 & 111245 \\
\hline Canoinhas & 179619 & 191792 & 218543 & 211744 & 314081 & 252019 & 237384 & 329224 & 343969 & 295688 & 386280 & 387408 \\
\hline \multicolumn{13}{|c|}{ Produtividade da soja em Santa Catarina (em kg/ha) } \\
\hline Curitibanos & 2581 & 1448 & 1273 & 2027 & 2823 & 2415 & 2443 & 3063 & 3100 & 2515 & 2688 & 3493 \\
\hline Xanxerê & 2969 & 2143 & 1641 & 2670 & 2964 & 2444 & 2916 & 3281 & 3435 & 2106 & 3282 & 2901 \\
\hline Joaçaba & 2647 & 1793 & 1435 & 2002 & 2519 & 2274 & 2404 & 3002 & 3026 & 2660 & 2841 & 3309 \\
\hline Chapecó & 2504 & 1781 & 1173 & 2413 & 2538 & 2358 & 2337 & 2938 & 3066 & 1772 & 2810 & 2572 \\
\hline São Miguel do Oeste & 2855 & 1876 & 1229 & 2444 & 2668 & 2388 & 2067 & 2948 & 3218 & 1540 & 2680 & 2171 \\
\hline Campos de Lages & 2678 & 2074 & 2078 & 1637 & 2376 & 2526 & 2128 & 2442 & 2875 & 2708 & 2708 & 2684 \\
\hline Canoinhas & 2844 & 2509 & 2664 & 2550 & 3252 & 2951 & 2652 & 3362 & 3471 & 3233 & 3500 & 3228 \\
\hline
\end{tabular}

Tabela 02 - área plantada de soja e milho, produção e produtividade de soja nas principais microrregiões de Santa Catarina - 2003-2014

Fonte: IBGE (2015)

As microrregiões que apresentaram o maior crescimento em área plantada de soja, entre 2003 e 2014, foram: Campos de Lages com uma taxa de 1.259\% (38,4 mil ha); Joaçaba que apresentou uma taxa de quase 290\% (30,8 mil ha); São Miguel do Oeste que apareceu com uma percentagem de 173,3\% (22,4 mil ha); Curitibanos com um percentual de 131,8\% (49,1 mil ha); Canoinhas com aumento de cerca de 90\% (56,8 mil ha); Chapecó com índice de 88, 2\% (39,1 mil ha); Xanxeré expressou uma taxa de $62,9 \%$ (50,8 mil ha).

Essas mesmas microrregiões apresentaram queda na participação da área plantada do milho. A maior queda foi na microrregião de Chapecó, onde o percentual atingiu a $65,6 \%$, uma redução de 132,1 mil 
ha entre 2003 e 2014. Na microrregião de Xanxeré a percentagem alcançou 58,8\% e o volume de hectares ficou na casa de 50,3 mil. Na microrregião de São Miguel do Oeste a perda de espaço do milho representou em 12 anos 69 mil ha, que corresponde a uma redução de área plantada de 55,8\%. As microrregiões de Curitibanos e Canoinhas apresentaram um índice de queda na área plantada do milho de 41,9\% e 40,2\% (21,2 mil ha e 31 mil ha), respectivamente. E as microrregiões de Joaçaba e Campos de Lages expressaram as menores taxa de queda da plantação de milho com, pela ordem: 26,37\% (23 mil ha); 19,44\% (9,1 mil ha).

Em termos de quantidade produzida e rendimento médio de grãos de soja pelas microrregiões de Santa Catarina, entre 2003 e 2014, destacam-se: Canoinhas produzia 179,6 mil toneladas e pulou para 387,4 mil toneladas, um acréscimo de 115,6\%, com uma produtividade de média de 3,22 toneladas por ha no final do período; Xanxeré aumentou sua produção 59,1\%, passando de 239,7 mil toneladas produzidas para 381,6 mil, mantendo estável, no período, sua produtividade; Curitibanos ampliou sua capacidade de produção de 96,2 mil toneladas para 301,9 mil, crescimento equivalente a $213,7 \%$, além de aumentar seu rendimento médio em 912 quilos por hectare no intervalo; Chapecó sai de 111,2 mil toneladas para 215 mil e sua produtividade permaneceu equilibrada na marca de 2,5 toneladas por hectares; Joaçaba, no período em tela, aumentou sua produtividade média em $25 \%$ e sua produção em 386,7\%, marcando 137,2 mil toneladas em 2014; Campos de Lages expandiu sua produção cerca de 14 vezes, saindo de 8,1 mil toneladas para 111,2 mil, com um rendimento médio de 2,6 toneladas por hectares; São Miguel do Oeste mais que dobrou sua produção, evoluiu de 37 mil toneladas para 76,9 mil, porém, teve queda da produtividade média, saindo de 2,8 toneladas por hectares para 2,1 toneladas. A figura 02 demonstra através de uma sequência de cartogramas à evolução do plantio da soja no estado de Santa Catarina entre os anos 1990 a 2015. 


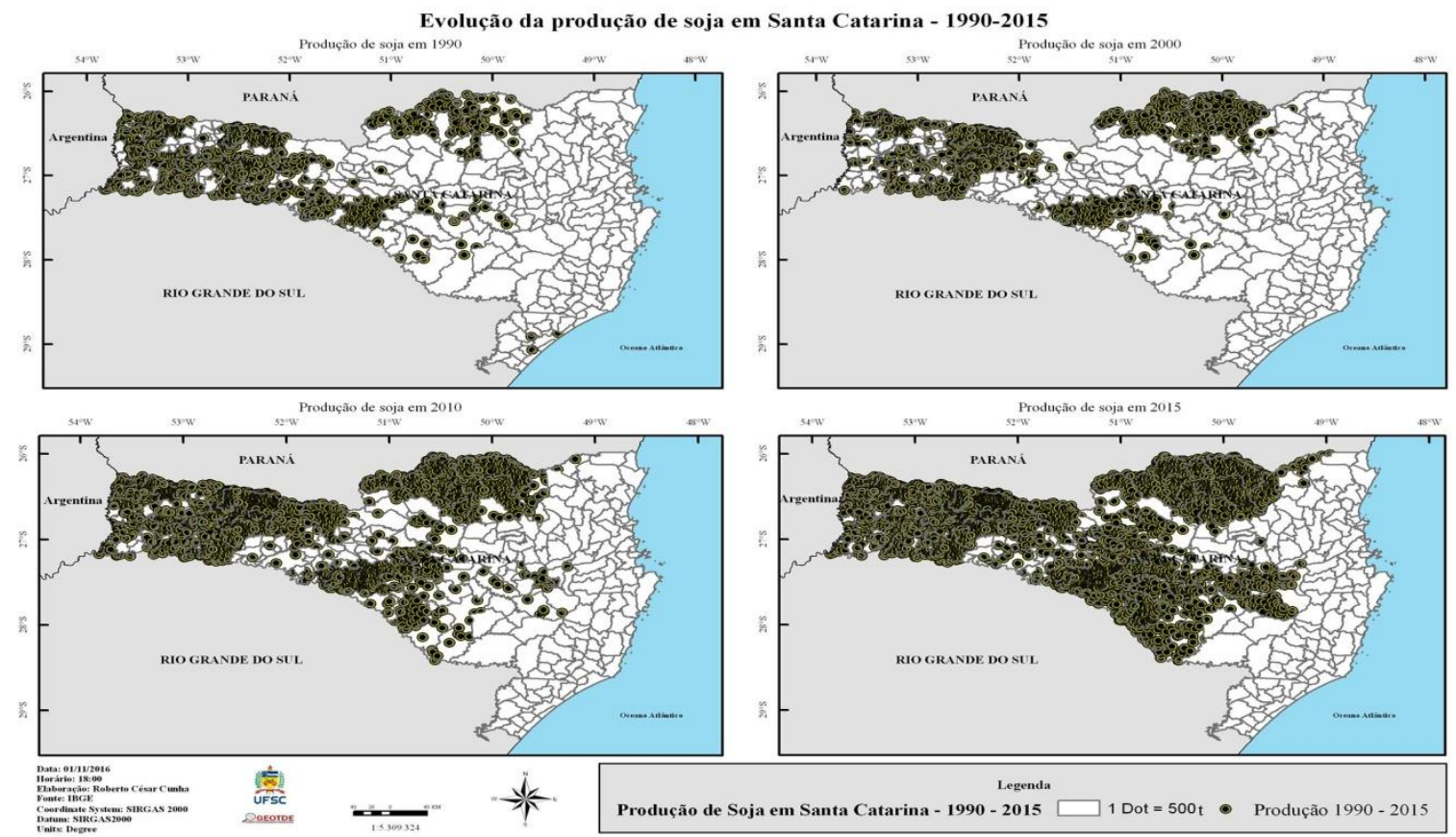

Figura 2: Evolução da produção de soja em Santa Catarina - 1990-2015.

Fonte: IBGE. Organização: autores

Ademais, na análise da área plantada da soja e do milho em Santa Catarina, patentemente percebe-se que há uma substituição da área tradicional da soja (Oeste Catarinense e Vale do Rio do Peixe) para área de expansão, precisamente, planalto serrano catarinense, planalto norte. Sem negligenciar a visão de conjunto da sociedade e sem descuidar das determinações específicas de cada microrregião de Santa Catarina, fica evidente que não uma aptidão exclusiva para determinadas formas das forças produtivas, pois, segundo Santos (1977, p. 89):

[...] a realização prática de um dos momentos da produção supõe um local próprio, diferente para cada processo ou fração do processo; o local torna-se assim, a cada momento histórico, dotado de uma significação particular. A localização num dado sítio e num dado momento das frações da totalidade social depende tanto das necessidades concretas de realização da formação social quanto das características próprias do sítio. 0 uso produtivo de um segmento de espaço num momento é, em grande parte, função das condições existentes no momento. De fato, o espaço não é uma simples tela de fundo inerte e neutro.

Esse dinamismo manifestou-se não apenas na esfera da produção, mas também no campo da circulação, embora não na mesma proporção que à elevação da produtividade da cultura da soja (e também de outros seguimentos produtivos), o que implica em uma série de gargalos a serem resolvidos por agentes públicos e privados como veremos na próxima seção. 


\section{TRANSPORTE E LOGÍSTICA DA SOJA EM SANTA CATARINA: rotas e demandas}

\section{infraestruturais}

O desempenho de um sistema de logística e transportes de uma região também depende de como estão organizados os processos de transações comercias, sobre os quais o Estado tem influência significativa. Para avaliar as necessidades de infraestrutura de logística e transporte, faz-se necessário conhecer os fluxos de bens das diversas cadeias produtivas.

Uma das determinantes do sucesso ou fracasso das cadeias produtivas de uma região é a facilidade de acesso aos recursos produtivos e ao mercado consumidor, pela capacidade dos operadores e intermediários logísticos que atuam na região e pela forma como as empresas, participantes da cadeia, se organizam e interagem.

Como já destacamos em nossa introdução, grande parte da produção dos principais insumos das agroindústrias de carnes - em especial milho e soja - se encontra fora do território catarinense. Historicamente, o estado é deficitário na produção de milho e soja, devido ao grande rebanho de aves, suínos, e, mais recentemente, também de vacas leiteiras. Como o consumo animal cresce constantemente, os maiores déficits estão nos anos de maiores problemas na oferta de desses grãos, especialmente o milho. De acordo com o Plano Estadual de Transportes e Logística do Estado de 2013 (PELT-SC), a média de déficit tem sido, de 2005 até 2010, da ordem de 1,5 milhão de toneladas, representando cerca $30,7 \%$ do consumo. Santa Catarina se abastece de outros estados, além de importar soja e milho dos países vizinhos, principalmente Paraguai. Os significativos volumes movimentados destes insumos, como mostra a figura 6, e os altos custos dos fretes associados ao fluxo destes produtos constituem um obstáculo à competitividade da indústria catarinense. Vale ressaltar que os polos de produção destes insumos têm se deslocado na direção centro/nordeste do país — região conhecida como Matopiba - ao longo dos últimos anos. Este deslocamento vem provocando aumento dos custos de transportes com perda crescente da competitividade da indústria catarinense (PELT-SC, 2013) 
Ao analisar a indústria de fabricação de alimentos para animais, observa-se uma concentração de empresas no estado do Paraná, onde estão 709 empresas de produtos amiláceos e alimentos para animais, as quais fornecem grande parte da ração das aves e suínos de Santa Catarina. Em Santa Catarina estão instaladas 376 empresas, na sua maioria empresas de pequeno porte (IBGE, 2016).

É importante destacarmos que a matriz de transporte pela qual a soja circula em Santa Catarina é basicamente a rodoviária, isso porque o estado carece que uma linha ferroviária que conecte o oeste catarinense - principal destino consumidor de soja e milho - sendo que, a maior parcela da soja que percorre pelas estradas de ferro que dão acesso ao Porto de São Francisco do Sul são oriundas de outras unidades federativas e com destino à exportação.

Britto \& Alvarenga (2006) destacam que aquisição da Brasil Ferrovias S/A pela América Latina Logística (ALL) ocorrida em 2006, levou a concentração e o monopólio do grupo na operação de granéis em ferrovias localizadas no centro-sul do país, pois a Brasil Ferrovias S/A operava três malhas ferroviárias concentradas no centro-oeste e sudeste do país, enquanto a ALL já monopolizava o transporte de granéis no sul. Com isso, a ALL representou uma concentração no mercado de transporte ferroviário de commodities agrícolas aos portos brasileiros.

Em instrução complementar o Conselho Administrativo de Defesa Econômica (CADE) verificou que a exportação da soja e derivados produzidos na região centro-oeste do Brasil pode seguir duas rotas logísticas envolvendo o modal ferroviário. A primeira rota, ligada pela Ferroban, tem como origem o Terminal de Alto Taquari e como destino o Porto de Santos. A segunda rota, operada pela ALL, liga Maringá (PR), Londrina (PR) e Ourinhos (SP) aos portos de Paranaguá (PR) e de São Francisco do Sul (SC). O CADE confirmou a relação de concorrência entre as duas rotas, para um determinado conjunto de exportadores. Concluiu, assim, que a aprovação do ato de fusão da Brasil Ferrovias S/A com a ALL geraria sérias preocupações de natureza concorrencial e, em particular, que os exportadores de soja originária da região centro-oeste do país passariam a se defrontar com um monopólio no transporte ferroviário de seus produtos até os principais portos de embarque para o exterior. Desta feita, o CADE recomendou a aprovação com restrições, exigindo a assinatura de um 
Termo de Compromisso de Desempenho estipulando metas de produtividade a serem alcançadas pela nova empresa, bem como especificando restrições comportamentais (BRITTO; ALVARENGA, 2006).

Entretanto, o aumento significativo no preço do frete da soja apontado pela Associação Nacional dos Transportadores Ferroviários (ANTF, 2016), nos leva a compreender que a operação elevou o poder do grupo ALL nos preços dos fretes ferroviários, na medida em que reduziu a competição no mercado. Além disso, indica que as restrições para aprovação impostas pelo CADE não foram suficientes para evitar que houvesse o abuso desse poder. Dessa forma, os produtores de soja, bem como seus consumidores, atingidos indiretamente, foram substancialmente prejudicados pela fusão.

Já os portos de Santa Catarina, historicamente, tiveram sua gênese relacionada principalmente a atividade pesqueira e também com a produção de óleo de baleia, sendo que alguns deles eram também inicialmente armações baleeiras, como no caso de Imbituba (SC). Os portos eram polivalentes, e eram operados por colonos, imigrantes e escravos durante os séculos XVIII e XIX, como relatam Silva (1992) e Leite (1996). Admite-se que até a metade do século XX, os portos de Santa Catarina ainda eram bastante rudimentares pois, além das baixas no que se refere à especialização dos serviços oferecidos e da mão de obra, os terminais também eram tecnologicamente muito defasados e usavam-se de técnicas arcaicas no manuseio de cargas para os padrões na primeira metade do século XX.

Com o desenvolvimento e a difusão das relações capitalistas no estado de Santa Catarina, a divisão social e territorial do trabalho promove uma intensa especialização produtiva das regiões catarinenses, especialmente, após a segunda metade do século XX como demonstra Mamigonian (1986; 2000; 2011). Nesse contexto, os portos catarinenses foram gradativamente se especializando na movimentação de determinadas cargas para atender às demandas dos exportadores regionais. Sendo assim, Itajaí que entre os anos 1940 e 1960 era conhecido por ser porto madeireiro ${ }^{9}$, foi aos poucos se especializando na movimentação de cargas congeladas conteinerizadas, especialmente carnes oriundas

\footnotetext{
${ }^{9}$ A queda das exportações de madeira na década de 1960 em Santa Catarina é atribuída a criação do Instituto Brasileiro de Desenvolvimento Florestal (IBDF) em 1967.
} 
das grandes agroindústrias do oeste catarinense, dando as bases para a configuração atual das cidades Itajaí e Navegantes ${ }^{10}$, que formam a maior aglomeração geográfica de prestadores de serviços logísticos (PSLs) com especialização em contêineres refrigerados no Brasil (CRUZ; FRAZZON, 2017); O Porto de Imbituba, historicamente conhecido como porto carbonífero que, a rigor, atende às exportações de carvão mineral do sul do estado de Santa Catarina, vem ampliando seu leque de atuação desde o ano 2012, quando à autarquia estadual SCPar assumiu à administração do porto em dezembro do mesmo ano, desde então, o Porto de Imbituba passou a também movimentar granéis agrícolas, como soja, milho e trigo; localizado na Baía do Babitonga; o Porto de São Francisco do Sul (SC) é o porto de Santa Catarina que mais movimenta cargas (em peso) do estado, isso porque além de conter uma estrutura própria para receber granéis sólidos, como esteiras para grãos, conexão ferroviária, além de uma unidade da trading Bunge, ao lado do porto, que contém silos e armazéns para granéis sólidos. Vale ressaltar que parcela majoritária dos grãos que são exportados pelo porto de São Francisco do Sul são oriundos de outras unidades federativas, em especial do Paraná e do Mato Grosso do Sul. Todos esses aspectos fazem o Porto de São Francisco do Sul ser o largamente o maior movimentador de soja do estado de Santa Catarina (tabela 1). Já o terminal privado de Itapoá (SC), também localizado na Baía do Babitonga, foi inaugurado no ano de 2011 e movimenta em essência cargas conteinerizadas, com baixa movimentação de cargas break bulk e granéis. 0 terminal portuário de Itapoá foi eleito pelo Instituto de Logística e Supply Chain (ILOS) como o terminal portuário mais moderno, com mais agilidade e segurança na movimentação de contêineres do Brasil entre 2014 e 2015.

Exportação de soja nos portos de Santa Catarina entre os anos de 2010 a 2015 (valores em US\$ e peso em ton.)

\begin{tabular}{|c|c|c|c|c|c|c|c|}
\hline Portos & $\begin{array}{c}\text { Unidade } \\
\text { de } \\
\text { medida }\end{array}$ & 2010 & 2011 & 2012 & 2013 & 2014 & 2015 \\
\hline & Valor & 1.142 .655 .56 & 1.309 .638 .13 & 1.493 .423 .64 & 2.151 .720 .05 & 2.506 .400 .41 & 1.771 .850 .21 \\
\hline $\begin{array}{l}\text { Sorto de } \\
\text { São }\end{array}$ & em US\$ & 7 & 2 & 6 & 7 & 8 & 8 \\
\hline Francisco & Peso em & 3.044 .282 .04 & 2.609 .398 .41 & 2.880 .517 .74 & 4.032 .263 .53 & 4.910 .908 .60 & 4.614 .863 .51 \\
\hline do Sul* & ton. & 6 & 0 & 9 & 6 & 4 & 6 \\
\hline
\end{tabular}

\footnotetext{
${ }^{10} \mathrm{O}$ terminal privado da Portonave em Navegantes foi inaugurado dia 21 de outubro de 2007, e atualmente é o terminal que mais movimenta contêineres em Santa Catarina, sendo atualmente o responsável pela movimentação de mais $60 \%$ dos contêineres do estado (CRUZ, 2016).
} 


\begin{tabular}{|c|c|c|c|c|c|c|c|}
\hline & $\begin{array}{l}\text { Valor } \\
\text { em US } \$\end{array}$ & - & - & - & - & 278.694 .084 & 109.409 .512 \\
\hline Porto de & Peso em & & & & & & \\
\hline \multirow[t]{2}{*}{ Imbituba } & ton. & - & - & - & - & 513.574 .100 & 254.156 .116 \\
\hline & $\begin{array}{l}\text { Valor } \\
\text { em US\$ }\end{array}$ & - & - & - & 971.795 & 7.237 .767 & 1.790 .763 \\
\hline $\begin{array}{l}\text { Porto de } \\
\text { Itajaí** }\end{array}$ & $\begin{array}{l}\text { Peso em } \\
\text { ton. }\end{array}$ & - & - & - & 1.795 .500 & 12.763 .060 & 4.064 .290 \\
\hline \multirow{4}{*}{ Total } & Valor & 1.142 .655 .56 & 1.309 .638 .13 & 1.493 .423 .64 & 2.152 .691 .85 & 2.792.332.26 & 1.883 .050 .49 \\
\hline & em US\$ & 7 & 2 & 6 & 2 & 9 & 3 \\
\hline & Peso em & 3.044 .282 .04 & 2.609.398.41 & 2.880 .517 .74 & 4.034 .059 .03 & 5.437 .245 .76 & 4.873 .083 .92 \\
\hline & ton. & 6 & 0 & 9 & 6 & 4 & 2 \\
\hline
\end{tabular}

Tabela 03 - Exportação de soja em Santa Catarina (US\$ e peso em toneladas) do ano de 2010 a 2015.

* Incluí os dados do Porto de Itapoá (SC).

**Incluí os dados do Terminal de Navegantes (SC).

Fonte: Ministério da Indústria, Comércio Exterior e Serviços (Alice Web) (2016). Elaboração: autores.

Como podemos confirmar na tabela 03, o Porto de São Francisco do Sul movimentou no ano de 2015 94,7\% de toda a soja exportada pelo estado de Santa Catarina. Entretanto, esse cenário já foi de 100\% até o ano de 2012, pois com início das exportações de soja pelo Porto de Imbituba, parcela da soja passou a ser direcionada para o porto da região sul do estado, que atualmente movimenta cerca de $5,2 \%$ da soja exportada por Santa Catarina. Enquanto isso, Itajaí/Navegantes representam apenas 0,08\% da movimentação da soja dos portos catarinenses.

A crise econômica que perpassa o Brasil, começou a dar sinais no ano de 2013, e foi agravada com a crise política causada após as eleições de 2014, tendo graves consequências ao setor marítimo portuário. Evidentemente, alguns terminais portuários foram mais impactados com a crise que outros, principalmente os terminais especializados na movimentação de cargas importadas conteinerizadas — duramente afetadas pela alta do dólar —, como o caso do porto público de Itajaí que concedeu os berços 1 e 2 para o operador logístico multinacional APM Terminals ${ }^{11}$ desde 2007, que adquiriu todos

\footnotetext{
${ }^{11}$ No Brasil, a APM Terminals administra as instalações portuárias de Itajaí e Pecém (CE). A empresa também é acionista da Brasil Terminal Portuário (BTP), em Santos (SP). Em todo o mundo, as operações estão espalhadas por 59 países, somando 64 portos e terminais, com sete novos projetos em desenvolvimento. No total, existem 20.600 trabalhadores distribuídos em cinco continentes trabalhando para o grupo APM Terminals (TECNOLOGÍSTICA, 2016).
} 
os direitos de operação do antigo TECONVI. A APM Terminals Itajaí S/A chegou a ficar no início do ano de 2016 com até 70\% de ociosidade de suas instalações para contêineres. Os terminais portuários vêm buscando compensar as perdas das cargas de importação com mercadorias de exportação, em especial, com granéis agroalimentares como a soja e o milho, impulsionados pela desvalorização cambial. Nesse sentido, os portos de São Francisco do Sul e de Imbituba não foram tão impactados pela crise como o complexo portuário de Itajaí e Navegantes.

Diante de um cenário de crise e quedas bruscas na movimentação de contêineres, o Porto de Itajaí busca diversificar a tipologia das cargas movimentadas. Entre 2014 e 2015, houve uma redução de quase $22 \%$ nas operações do porto público. A alternativa imediata tem sido o aumento da movimentação de granéis. Alguns cargueiros de soja atracaram em Itajaí desde março de 2016, mas o porto precisa passar por drásticas adaptações internas e de acessibilidade para não perder a rota para portos como São Francisco do Sul que é um porto com tradição e infraestrutura adaptada para o manuseio desse tipo de carga. Além da movimentação de soja, o Porto de Itajaí (porto público) também estuda a possibilidade de operar trigo, madeiras em toras e carros. Já em Navegantes, o terminal privado não tem interesse em diversificar a tipologia das cargas operadas e, por enquanto, continuará movimentando apenas contêineres (CRUZ, 2016).

De acordo com a Revista Portuária de Economia e Negócios (2016), a soja cuja movimentação está sendo negociada para ocorrer no Porto de Itajaí é do tipo orgânica e há uma exigência dos importadores de que ela seja embarcada por um terminal que não movimente soja transgênica, para evitar a mistura. Partindo dessa premissa, os agentes locais de Itajaí vislumbram um novo nicho de mercado, pois, em grande medida, os portos de São Francisco do Sul e de Imbituba movimentam soja do tipo transgênica.

Algumas alternativas para movimentar a carga a granel estão em estudo. A primeira alternativa é a de que o operador construiria um armazém inflável no Porto de Itajaí, próximo aos berços 3 e 4 . A soja chegaria de caminhão ao porto público, seguiria descarregada neste armazém, colocada em contêineres especiais, que levados ao navio, teriam um fundo que se abriria e a soja seria estocada nos porões do 
navio. Isso porque o Porto de Itajaí não tem esteiras que levam a soja até os navios. A segunda opção seria o operador alugar um dos vários galpões disponíveis ao longo da BR-101, ou próximos, para estocar soja fora da cidade de Itajaí. Os contêineres seguiriam para o porto cheios, mas sem derramar soja pelo caminho, seriam erguidos para os navios e despejariam a soja nos porões. Neste caso, a operação exigiria um local alfandegado, o que pode atrasar as negociações (REVISTA PORTUÁRIA ECONOMIA \& NEGÓCIOS, 2016).

Entretanto, algumas ressalvas devem ser esclarecidas, pois atualmente não há infraestrutura, tanto portuária quanto rodoviária, para se trabalhar com cargas a granel em Itajaí. Destarte, alguma medida precisa ser tomada para evitar a falência do porto público de Itajaí. Nesse sentido, quando as cargas de maior valor agregado deixam de circular, uma boa alternativa é adaptar a estrutura ociosa para receber lotes de granéis, especialmente soja e milho. A movimentação de soja seria um paliativo para retomar a movimentação em Itajaí. Apesar de não ser competitivo como o Porto de São Francisco do Sul no setor graneleiro, as autoridades do Porto de Itajaí perceberam à necessidade de os terminais terem uma estrutura flexível para não ficarem reféns da movimentação das cargas conteinerizadas.

Enquanto o Porto de Itajaí encerrou 2015 com queda nas movimentações, São Francisco do Sul apresentou aumento de 11,9\% no terceiro trimestre do mesmo ano (ANTAQ, 2016). De acordo com a Antaq (2016), esse melhor desempenho no Porto de São Francisco do Sul está atrelado ao volume de suas movimentações de cereais, sementes e frutos oleaginosos, que apresentaram crescimento expressivo, principalmente por parte da soja e do milho, impulsionados com a alta do dólar.

A alta do dólar frente ao real contribuiu para uma melhora no preço interno das commodities, amenizando a queda do preço internacional, que em agosto de 2015 registou o menor valor cotado desde março de 2009 (US\$ 322,46/T). Como pode se observar no levantamento da Antaq, no ano de 2015, a movimentação de granéis, tanto líquido quanto sólido, somam juntos mais de 86\% de toda a movimentação de cargas do país (Gráfico 01). 


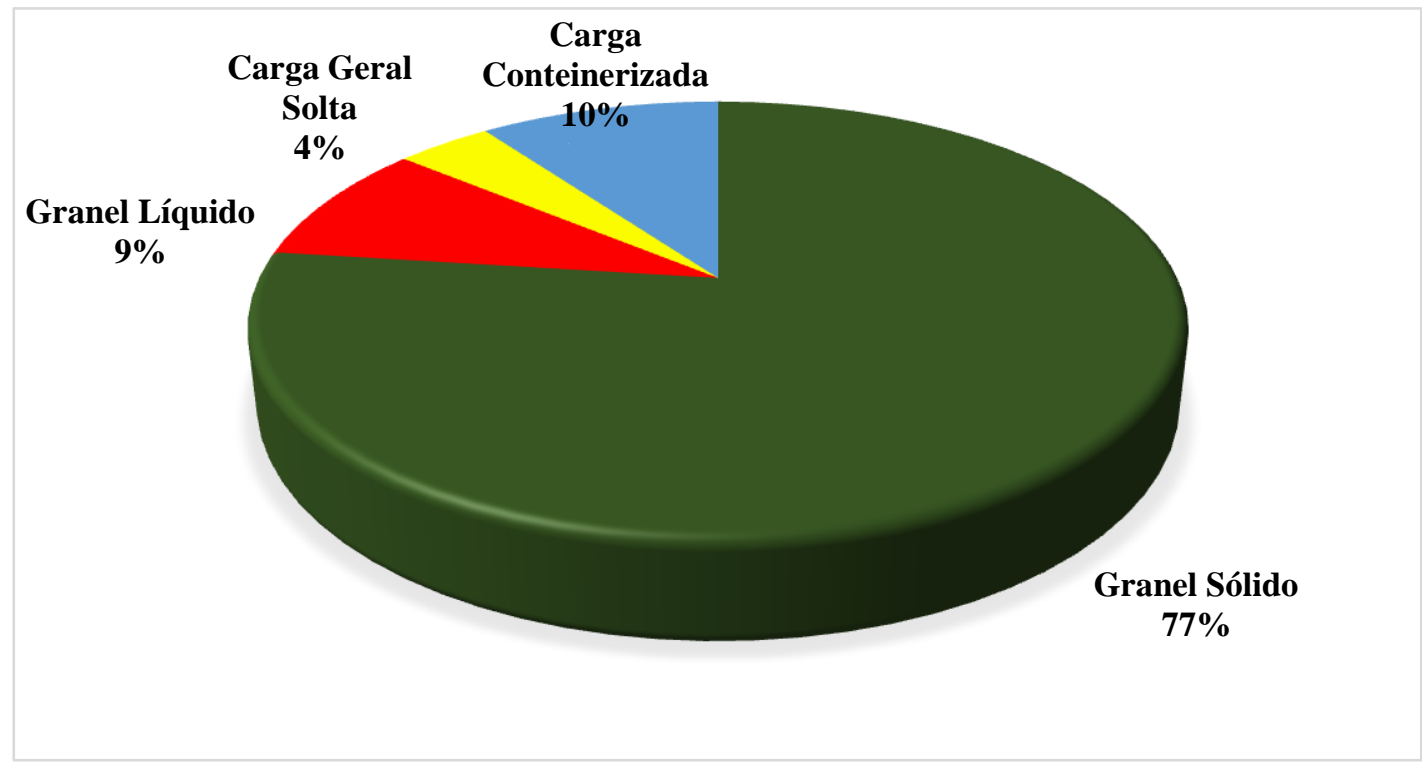

Gráfico 1. Perfil das cargas exportadas no Brasil em 2015 (em toneladas).

Fonte: ANTAQ, 2016. Elaboração: autores.

Em comparação ao ano de 2014, em 2015 as exportações de granéis sólidos no Brasil aumentaram $+7,24 \%$, os granéis líquidos diminuíram em - 2,39\%, as cargas gerais soltas aumentaram em + 5,71\% e a movimentação de contêineres diminuiu em - 1,13\% (ANTAQ, 2016). Com essas mudanças no perfil das cargas movimentadas, os terminais portuários, bem como os PSLs, que não flexibilizarem suas estruturas para que possam receber cargas de diversas tipologias, ficam mais à mercê da conjuntura econômica comparativamente a outros operadores logísticos que contam com uma infraestrutura mais factível de mudanças em caso de alterações no perfil de cargas movimentadas no comércio exterior. Atualmente, o transporte e o armazenamento de granéis vêm se mostrando o mais seguro e menos propenso a ser impactado por crises econômicas, uma vez que, nas últimas quatro décadas no Brasil, o setor agroalimentar têm apresentado à característica de ser o último setor a entrar em crises econômicas, assim como também é primeiro a sair das mesmas e ter à retomada do crescimento econômico.

Embora as infraestruturas portuárias de Santa Catarina sejam diversificadas, o estado monstra uma grande dependência do modal rodoviário, especialmente nas relações leste-oeste do estado. 0 uso do transporte rodoviário para o transporte de grandes volumes de mercadorias a grandes distâncias encarece consideravelmente os custos logísticos dos produtos do agronegócio, pois de acordo com uma 
pesquisa recente da Fundação Dom Cabral (2015), os custos logísticos são responsáveis por cerca de $11,67 \%$ dos custos dos produtos do agronegócio.

Além dos custos logísticos, é provável que em um futuro não muito distante, surjam mais imperativos para a construção de plataformas logísticas no estado de Santa Catarina, pois os congestionamentos no trânsito (especialmente nos acessos da BR-101 à Florianópolis e Itajaí) os acidentes com mortes e avarias de cargas, a degradação ambiental, os atrasos nas entregas e retiradas de contêineres etc., causados pela histórica ausência de planejamento territorial voltados para a logística, e a construção e o uso de infraestruturas de transportes alternativas (ferrovias e cabotagem) para às atividades de transportes e logística em Santa Catarina. Esses problemas estão se tornando cada vez mais agravantes que pressionam as políticas públicas, uma vez que os mesmos têm sido constantemente noticiados pela imprensa em diversas escalas. Silva et al (2013) nos lembra que as plataformas logísticas podem colaborar para minimizar os diferentes impactos causados nos centros urbanos pela frequente utilização de veículos de cargas de forma não otimizada ou mesmo sem o planejamento adequado.

\section{CONCLUSÕES}

Podemos ressaltar que os avanços tecnológicos referentes à produção da soja, resultaram em um grande aumento de produtividade por área da referida cultura no Brasil desde a década de 1990. Esse avanço se deve, em especial, aos maciços investimentos em pesquisa e desenvolvimento por empresas privadas e, principalmente, públicas como a Embrapa. Estimulados com a alta dos preços das commodities, diversos produtores passaram a optar pelo plantio da soja em detrimento à outras culturas que historicamente foram mais relevantes em algumas regiões, como o caso do milho em Santa Catarina, que perdeu área para a soja.

A soja em Santa Catarina experimentou um crescimento considerável nas duas primeiras décadas do século XXI, tanto que tange a área plantada como na produtividade por hectare. Entretanto, vale ressaltar que Santa Catarina não é autossuficiente na produção de milho, principal insumo das grandes 
agroindústrias de carnes localizadas à na porção oeste do estado, ou seja, à ampliação da soja em Santa Catarina implica em também aumento das importações de milho de outras unidades federativas e de países vizinhos como Paraguai e Argentina.

No que concerne às infraestruturas de transportes e armazenamento, fica claro que os mesmos estão em via de tornarem-se gargalos que atenuam às margens de lucro dos produtores de soja, isso porque o uso em grande escala do modal rodoviário para o transporte de grãos eleva os custos logísticos. Entretanto, a alta produtividade e os custos de produção da soja atenuam os impactos dos custos logísticos no Brasil e, inclusive, em Santa Catarina.

A necessidade da criação de plataformas logísticas e da ampliação das infraestruturas intermodais de transportes (especialmente estradas de ferro) no território brasileiro e de Santa Catarina, têm se tornado cada vez mais imperativa, uma vez que as rodovias enfrentam um inchaço devido ao aumento da frota de veículos no Brasil nos últimos 50 anos, e também, o aumento dos preços dos combustíveis que encarece os preços dos fretes, assim como às recentes mudanças na legislação trabalhista para motoristas. À necessidade de criação de plataformas logísticas e do uso do transporte intermodal não é algo apenas para satisfazer os imperativos da circulação de mercadorias e pessoas, mas também deve ser feita em uma perspectiva de atenuar problemas socais como: acidentes de transito, mortes em rodovias, etc.; e problemas ambientais como emissão de poluentes, descarte de resíduos industriais e de veículos em lugares inapropriados.

Cabe lembrar que uma formação socioespacial concreta não se reduz, simplesmente, a homogenia de suas próprias forças produtivas e nem as suas próprias relações sociais de produção dominantes. As diferentes formas de produção e reprodução (material, política, natural, jurídica) não caminham concomitantemente, cada uma tem seu passo, seu ritmo. Cada uma tem sua temporalidade no mesmo espaço. E essas formas de produção juntos com as relações que produzem, se combinam com outras forças produtivas e relações de produção derivadas, transpostas de outras formações socioespaciais. No Brasil são nítidas essas diferenciações devido um conjunto de combinações naturais, culturais e econômicas. E essas diferenciações não-contemporâneas não querem dizer que são apenas as 
desigualdades em diferentes momentos, mas sim, também, é o processo de desenvolvimento delas de forma desigual e combinado em um novo espaço e tempo histórico.

\section{REFERÊNCIAS BIBLIOGRÁFICAS}

BARAT, J. Infraestruturas de logística e transporte: análise e perspectivas. In: SILVEIRA, M. R. (Org.). Circulação, transportes e logística: diferentes perspectivas. São Paulo: Outras impressões, 2011. p.217-246.

Logística e transporte no processo de globalização: oportunidades para o Brasil. São Paulo: Editora Unesp,

2007.

BARBOSA, N. Dez anos de Política Econômica. In: SADER, E. (Org.). 10 anos de governos pós-neoliberais no Brasil: Lula e Dilma. São Paulo; Rio de Janeiro: Boitempo; Flacso, 2013. p. 63-101.

BERTRAND, J. LAURENT, C. LECLERCQ, V. O mundo da soja. São Paulo: Hucitec, 1987.

BIELSCHOWSKY, R. Estratégia de Desenvolvimento e as Três Frentes de Expansão no Brasil: um desenho conceitual. Texto para Discussão. n. 1828, Brasília: IPEA. abr. 2013.

. Pensamento econômico brasileiro: ciclo ideológico do desenvolvimentismo. Rio de Janeiro: $5^{\text {a }}$ Ed. Contraponto,

2000.

BONATO, E, R.; BONATO, A. L. V. A soja no Brasil: história e estatística. Londrina: EMBRAPA-CNPSo, 1987.

BONATO, E. R. Programa Nacional de Pesquisa de Soja. In: SEMINARIO NACIONAL DE PESQUISA DE SOJA, 2., 1981, Brasilia. Anais... Londrina : EMBRAPA-CNPSo, 1982. v.1 p.765-792. (EMBRAPA-CNPSo. Documentos, 1) BRASIL. Agência Nacional de Transportes Aquaviários (ANTAQ). Perfil das cargas transportadas em 2015. Disponível em < http://www.antaq.gov.br/Portal/PDF/Anuarios/ApresentacaoAnuario2015.pdf > acesso dia 27 de julho de 2016.

. Ministério da Agricultura, Pecuária e Abastecimento. Estatísticas de comércio exterior do agronegócio brasileiro. 2016. Disponível em: < agrostat.agricultura.gov.br/>. Acesso em: 27 set. 2016

Ministério da Indústria, Comércio Exterior e Serviços. Movimentação de soja nos portos de Santa Catarina. Disponível em < http://aliceweb.mdic.gov.br/ >. Acesso dia 27 de julho de 2016.

BRITTO, P. A.; ALVARENGA, B. R. Uma análise sobre os efeitos da fusão da ALL-Brasil no preço do frete ferroviário de soja no Brasil. ANPET, 2006. Disponível em $<$

http://www.anpet.org.br/ssat/interface/content/autor/trabalhos/publicacao/2013/129_AC.pdf > acesso dia 28 de julho de 2016 .

CAMPOS, M. C.A Embrapa/Soja em Londrina -PR: a pesquisa agrícola de um país moderno. 2010. 123 f. Tese (Doutorado) -Programa de Pós-Graduação em Geografia, Centro de Filosofia e Ciências Humanas, Universidade Federal de Santa Catarina, Florianópolis, 2010.

CASTRO, A. M. G. Cadeia produtiva: marco conceitual para apoiar a prospecção tecnológica. In: SIMPÓSIO DE GESTÃO DA INOVAÇÃO TECNOLÓGICA, 22., 2002, Salvador. Anais... Salvador: Fieb, 2002. v. 1, p. 1-14.

CEPEA. Centro de Estudos Avançados em Economia Aplicada. PIB cadeias agropecuárias. 2016. São Paulo: CEPEA. Disponível em: http://cepea.esalq.usp.br/pibpec/. Acesso em: 15 ago. 2016. 
CHOLLEY, A. Observações sobre alguns pontos de vista geográficos. Boletim Geográfico, Rio de Janeiro, n. 179, p. 139 $145,1964$.

CONAB. Companhia Nacional de Abastecimento. Séries históricas de produção de grãos. Brasília: 2016. Disponível em: $<$ http://www.conab.gov.br>. Acesso em: 13 ago. 2016.

CRUZ, W. L. M. O complexo portuário e logístico de Itajaí e Navegantes (SC): regulação, consolidação, demandas infraestruturais e dinâmica das empresas de transporte e logística. 2016. 241f. Dissertação (Mestrado) - Curso de Geografia, Geociências, Universidade Federal de Santa Catarina, Florianópolis, 2016.

CRUZ, W. L. M.; FRAZZON, E. M. A aglomeração geográfica dos prestadores de serviços logísticos (PSLs) nos municípios de Itajaí e Navegantes (SC): aspectos conceituais, economia espacial e desafios para o ordenamento dos fluxos no território. In: Formação Online. Presidente Prudente: Vol. 1, noํ2, 2017. (No prelo)

CUNHA, R. C. C. Gênese e dinâmica da cadeia produtiva da soja no Sul do Maranhão. 2015. 221f. Dissertação (Mestrado) Curso de Geografia, Geociências, Universidade Federal de Santa Catarina, Florianópolis, 2015

DALL' AGNOL, A. Soja: o fenômeno brasileiro. Londrina: EMBRAPA, 2004.

ESPÍNDOLA, C. J. As agroindústrias de carne do sul do Brasil. 2002. 268 f. Tese (Doutorado)- Curso de Geografia, Faculdade de Filosofia, Letras e Ciências Humanas, Universidade de São Paulo, São Paulo, 2002.

. A dinâmica geoeconômica do agronegócio brasileiro de carnes e soja. In: LAMOSO, L. P. (Org.). Temas do desenvolvimento econômico brasileiro e suas articulações com o Mato Grosso do Sul. Curitiba: Íthala, 2016. p. 19-53.

ESPÍNDOLA, C. J.; CUNHA, R. C. C. A dinâmica geoeconômica recente da cadeia produtiva de soja no Brasil e no Mundo. Geotextos, v. 11, n. 1, p. 217-238, Salvador, UFBA, 2015.

GIL, A. C. Métodos e técnicas de pesquisa social. Atlas: São Paulo, 1994.

HARA, C. M. Logística: armazenagem, distribuição e trade marketing. Campinas/SP: 5ª Edição, Editora Alínea, 2013. HASSE, G. O Brasil da Soja: Abrindo Fronteiras, Semeando Cidades. Florianópolis: Ceval, 1996.

HYMOWITZ, T.; VERNETTI, F. J.; SHANDS, H. L. The Brazilian national soybean program. Soybean Digest. May, 1968, p. 62-65.

IBGE. Instituto Brasileiro de Geografia e Estatística. Produção agrícola municipal: vários anos. 2016. Disponível em: <http://www.sidra.ibge.gov.br/bda/pesquisas/pam/default.asp?o=29\&i=P>. Acesso em: 15 jul. 2016.

ICEPA. Instituto de Planejamento e Economia Agrícola de Santa Catarina. Síntese Anual da Agricultura Catarinense. 2015. Disponível em: <http://www.epagri.sc.gov.br/?page_id=3210>. Acesso: 10 mar. 2016.

LEITE, I. B. Descendentes de africanos em Santa Catarina: invisibilidade histórica e segregação In: Negros do Sul do Brasil: invisibilidade e territorialidade. Florianópolis: Editora Letras Contemporâneas, 1996.

MAmigOniAN, A. Estudo geográfico das indústrias de Blumenau. Revista Brasileira de Geografia, Rio de Janeiro, v. 27 , n. 3, p. 387-481, jul./set., 1965 .

. Indústria de Santa Catarina: dinamismo e estrangulamento. In: MAMIGONIAN, A. (Org.). Santa Catarina: estudos de geografia econômica e social. Florianópolis: GCN/CFH/UFSC, 2011. p.73-120.

. Indústria. In: Atlas de Santa Catarina. Florianópolis (SC): Gaplan, 1986. 
. Teorias sobre a industrialização brasileira. Cadernos Geográficos, nº2, Florianópolis (SC), Ed. UFSC, 2000.

MARX, K. Grundrisse. Manuscritos econômicos de 1857-1858: esboços da crítica da economia política. São Paulo: Boitempo, 2011.

NAKAHODO, S. N.; JANK, M. S. A falácia da doença holandesa no Brasil. In: Documento de pesquisa. São Paulo: Icone, 2006.

OLIVEIRA, A. L. R. A logística do agronegócio: para além do "apagão logístico". In: BUAINAIN, M. A.; et al (Orgs). O mundo rural no Brasil do século XXI: formação de um novo padrão agrário e agrícola. Brasília/DF: Embrapa, 2014. p. 337 371.

PINHEIRO, A. C.; FRISCHTAK, C. R. (Orgs.). Gargalos e soluções nas infraestruturas de transportes. Rio de Janeiro: Editora da FGV, 2014.

PINHEIRO, A. C.; FUKASAKU, K. (Orgs.). A privatização no Brasil: o caso dos serviços de utilidade pública. Brasília: BNDES, 2000

PLANO ESTADUAL DE LOGÍSTICA E TRANSPORTE DE SANTA CATARINA (PELT) 2013. Disponível em: <http://nures.ufsc.br/wp-content/uploads/2012/09/Relatorio-Outubro-3010.pdf >. Acesso dia 08 de maio de 2016. RANGEL, I. Obras Reunidas. Rio de Janeiro: Contraponto/BNDES, 2005. Vol.1 e 2.

REVISTA PORTUÁRIA ECONOMIA E NEGÓCIOS. Diversificação de cargas pode ser a saída para o Porto de Itajaí. Itajaí (SC): Editora Bittencourt, ano 15, edição 192, fevereiro, 2016.

REVISTA TECNOLOGÍSTICA. Terminais Portuários: em meio à queda nas movimentações, empresas investem em estrutura, tecnologia e treinamento. São Paulo: Editora Publicare, ano XXI, nº243, mar/abr., 2016.

SANTOS, M. Espaço e Método. São Paulo: 5ª Ed., Editora da Universidade de São Paulo- Edusp, 2014.

Sociedade e espaço: A formação social como teoria e como método. Boletim Paulista de Geografia, São Paulo, v. 54, p. 81-100, jun. 1977 .

SANTOS, M; SILVEIRA, M. L.. O Brasil: território e sociedade no início do século XXI. Rio de Janeiro: Ed. Record, 2001.

SILVA, C. M. Ganchos/SC: Ascensão e decadência da pequena produção mercantil pesqueira. Florianópolis/SC: Ed. UFSC, 1992.

SILVA, R. M.; et. al. Governança em plataformas logísticas: uma análise dos elementos e atributos a serem considerados neste tipo de empreendimento logístico. In: Journal of Transport Literature. Manaus (AM): Vol. 7, n. 3, Jul. 2013, p. 240 269.

WAIBEL, L. Capítulos de geografia tropical e do Brasil, 2. ed. Rio de Janeiro: IBGE, 1979. 